\title{
THE CONCEPT OF AL-WIHDATUL WUJUD IBNU ARABI (A Sufistic Philosophical Study)
}

\author{
Nurhayati Abd Rasyid ${ }^{1}$ \\ ${ }^{1}$ Faculty of Islamic Phylopsophy, Institut Agama Islam Negeri Palu, Palu, \\ nurhayatiabdrasyid@iainpalu.ac.id
}

\begin{abstract}
This paper discusses the concept of Al-Wahdatul Wujud of Ibnu Arabi. Ibnu Arabi is a well-known philosopher in Islam and he was born in Sapin on $570 \mathrm{H}$. His philosophical concept and sufistic (Islamic mysticism) thought are mostly influenced by Ibn Rushd's and Ibn Sina's philosophy. Ibu Arabi argues that everything in nature has the essence of being which is similar to the concept of Al-Farabi's philosophy, with focus on the concept of emission (emanation) philosophy of Folotinus, "which says that the "One" is everywhere and there is no where as a cause. Ibnu Arabi uses the term absolute (al-wujud al-mutlaq) or universal form (al-wujud al Kully) to show reality of the ultimate humans' life. Absolute is not limited to any particular form, but is common to all forms of life. Absolute is also understood in the sense of not being in all forms but forms that transcend all the human beings.
\end{abstract}

Keywords: Ibnu Arabi, philosophy, Al-Wahdatul Wujud, Absolutism

\begin{abstract}
Abstrak. Makalah ini membahas konsep Al-Wahdatul Wujud Ibnu Arabi. Ibnu Arabi adalah seorang filsuf terkenal dalam Islam dan ia dilahirkan di Spanyol pada 570 hijriah. Konsep filosofis dan pemikiran sufistiknya Ibnu Arabi sebagian besar dipengaruhi oleh filosof Ibn Rushd dan Ibn Sina. Ibu Arabi berpendapat bahwa segala sesuatu di alam memiliki esensi seperti dikemukakan dalam filsafat Al-Farabi, dengan konsep emisi (emanasi) filsafat Folotinus," yang mengatakan bahwa "Yang Satu" ada di mana-mana dan \tidak ada tempat sebagai penyebabnya. Ibnu Arabi menggunakan istilah absolut (al-wujud al-mutlaq) atau bentuk universal (al-wujud al Kully) untuk menunjukkan realitas kehidupan manusia pamungkas. Mutlak tidak terbatas pada bentuk tertentu, tetapi umum untuk semua bentuk kehidupan. Mutlak juga dipahami dalam arti tidak berada dalam segala bentuk tetapi bentuk yang melampaui semua manusia.
\end{abstract}

Kata Kunci: Ibnu Arabi, filsafat, Al-Wahdatul Wujud, Absolutisme 


\section{Introduction}

The development of Sufism, originated in the individual activity of Sufi experts, they almost do not have the ability to transmit their knowledge to other people, this is because the science of tasauwf requires time, thoughts and feelings in order to find identity with a variety of "stations " (read Harun Nasutin Philosophy and Mysticism in Islam) in relation to Allah Almighty.

The journey of mind, observation and spiritual transcendence strive on the search for something "that is power" that is free from the dimensions of time, change, and dependence, the urge of desire and need for something runs gradually in tune with the level of intelligence and sharpness of the human intuition itself. ${ }^{1}$ To avoid error of mind and feeling in the search for something "that is Adi Kudrati" then it was in the sending of Muhammad, to convey the messages of God through the concept of the Qur'an, but the Qur'an, has a unique style of language, so that it can be understood by everyone in accordance with their level of intelligence, among humans there are those who tend to understand the verses of al-qur'an rationally, but not a few who try to find the secret of truth through the approach "spiritual esoteric or intuitive experience".

Many verses of the Qur'an affirm that only Allah is obliged to be worshiped, but do not provide concrete details about the form of Allah, meaning "what is Allah who is worshiped and who worship and what is the relationship with the universe?" Even though Allah has signaled through his perfection (Asma alHusnah) that humans always seek the secrets stored in the universe whose relationship between Allah as Khaliq (creator) and humans as creatures (servants), this problem is again unclear due to the emergence of various conceptions and types of thinking which are theological, philosophical or mystical. ${ }^{15}$

On this basis, the authors raise a concept of "Al-Wihdatul Wujud", a work of Ibn Arabi, which explains that everything in the universe is emanating from one form, namely; Allah SWT.

${ }^{1}$ P. A Rivai Siregar, Tasawuf dari Sufisme Klasik ke New Sufisme cet. II (Jakarta: Raja Grapindo Persada 2000), p. 58

${ }^{2} \mathrm{Ibid}$, p. 60

${ }^{15}$ Yusuf, B. (2016). Manusia Dan Amanahnya Kajian Teologis Berwawasan Lingkungan. Jurnal Aqidah-Ta, 2(2), 125-143. 


\section{Approach to this paper}

This paper is literature review in nature. The use of literature review method in writing a paper based on secondary data has been practiced previously. ${ }^{16}$ Firstly, the author indentified books and journal articles which published the concept of wahdatul wujud of Ibnu Arabi. The author searched the literature from offline and online library. From online library, the author use key words, such as "wahdatul wujud', Ibu Arabi, and the thought of Ibnu Arabi", on search engine to find the literature as suggested by Beel, Gipp, and Wilde. ${ }^{17}$ After that, the author, chategorized information related to the topis based on themes found in the literature from books and journal article. Finally, the paper is written and discuss the findings.

\section{Results and Discussion}

Biography

Sheikh Muhiddin Muhammad Ibn Ali, or so-called Ibn Arabi was born in Spain ( 570 H/1165 AD), he came from the tribe of al-Thay, an Arabic family of alHatimi, in general he came from a pious family and his parents himself was a Sufi who had a wandering habit. ${ }^{4}$ At the age of 8 years old he had wandered to Lisabon, to study religion with a pious ulama (Islamic scholar) named Sheikh Abu Bakr bin Khallaf, this is where he studied various disciplines such as: Theology, Ulumul Qur'an, Hadith, Islamic Law (Fighi) and others.

As an adult he began traveling in the footsteps of his father, in several countries such as: Sevilla as a meeting place for Sufis and settled there for 30 years, ${ }^{5}$ After that he moved again to Cordova to study with one of the famous philosophers in the West, Ibn Rushd and several years later he moved again to Morocco, Tunisia, Egypt, Jerusalem, Mecca, Hijaz, Aleppo, Asia Minor and finally settled in Damascus as a haven and at the same time exhale the last breath in 638 $\mathrm{H} / 1240 \mathrm{AD}^{6}$

From the experience of Ibn Arabi, it was apparently influenced by philosophical and Sufistic thoughts such as Ibn Rushd's philosophy, Ibn Sina's philosophy with the concept "that everything in nature has the essence of being"

${ }^{16}$ Snyder, H. (2019). Literature review as a research methodology: An overview and guidelines. Journal of Business Research, 104, 333-339.

https://doi.org/https://doi.org/10.1016/j.jbusres.2019.07.039

${ }^{17}$ Beel, J., Gipp, B., \& Wilde, E. (2010). Optimizing Scholarly Literature for Google Scholar \& Co. Journal of Scholarly Publishing 41(2), 176-190.

${ }^{4}$ Sayed Husein Nasr, Tiga Pemikir Islam, Ibnu Sina, Suhrawardi, Ibnu Arabi, (Bandung, Risalah,1986), p. 127

${ }^{5} \mathrm{Ibid}$,

${ }^{6}$ Rivai Siregar, Op Cit, p. 172 
Al-Farabi's philosophy, with the concept of emission (emanation) philosophy of Folotinus, "which says that the "One" is everywhere and there is no where as a cause ". Meanwhile, Sufism is influenced by Al-Hallaj's thoughts with the concept of Hulul, Abu Yasid al-Bustami's Ittihad, and Imam Al-Gazali with the concept of Ma'rifah. ${ }^{7}$

Besides that, Ibn Arabi also gave birth to some very influential works in the development of Sufism at that time revealed by Laily mansur in his book, "Teachings and Examples of the Sufis" including, Futuhat al-makkiyah, Tarjuman al-syiwaq, Fushushul Hikam. ${ }^{9}$ According to Ibn Arabi and many other works such as Sayed Hsein Nasr, that Ibn Arabi's work has around 560 titles. ${ }^{9}$

Thus, the experience and work of Ibn Arabi, it can be concluded that, he is a hunter of knowledge seen from a variety of experiences, but in this paper only one of his works, the foster writer Namely "The Concept of Al-Waihdatul Wujud" as in the following discussion:

\section{Definition of Being}

Before the author outlines the concept of al-Wihdatul form Ibn Arabi, the author first put forward the notion of al-Wihdatul form, or called the unity of form (pantheism), the word "form" (being al-wujud) and the words God, are "absolute forms (Allah Huwa al-Wujud, al-haaq)". In terms of form there are two meanings namely; form as a concept that means the idea of "being" or the existence of a form that has a basic meaning (bil ma'na al-masdari) or it can mean having a form, namely existing (subsistence) or living (subsists) (wujud bi ma'na maujud). ${ }^{10}$

So the term absolute form (al-wujud al-mutlaq) or universal form (al-wujud al-Kully) this concept is used by Ibn Arabi in showing a reality which is the peak of all that exists, besides that the term existence is identical to absolute, then in this term there are four meanings in existence as follows: Absolute in the sense that form is not limited to any particular form, but is common to all forms, second, absolute in the sense of not being in all forms but forms that transcend all. Third, absolute as a meaning that is not a cause "illat of all things, meaning a direct cause, and this is called the self-subsisting and the absolute free. Fourth, ordinary form that indicates as absolute to what is called reality". ${ }^{11}$

${ }^{7}$ Harun Nasution, Filsafat dan Mistisisme dalam Islam, (Jakarta, Bulan Bintang,1973), p. 82.87

${ }^{8}$ Laily Mansur (Read, According to Ibnu Arabi, Futuhat al-makkiyah was dictated from Allah, while Fushush al- Hikam was given by Rasulullah), p. 188

${ }^{9}$ Sayed Husein Nasr, Loc, Cit, p. 134

${ }^{10}$ A.E. Affifi, Filsafat Mistis ibnu Arabi, $2^{\text {nd }}$ Print, (Jakarta: CV Gaya Media Pratama, 1995),

${ }^{11}$ Ibid, 
Thus, what is meant in the concept of being, is an absolute unity, in essence the form is a universal substance of the whole being, in a source that comes from one form that is absolute, namely the form of God. As Ibn Arabi stated "if it was not because of the penetration of God through its forms, in all existence, then this world might not have existed, just as if it were not universal realities that could be understood (al Haqa'iq al Ma'qulq al Kulliyyah) then of course there will be no (ahkam) predictions about external objects". ${ }^{12}$

Starting from the illustration of Ibn Arabi above which illustrates that what is contained in the universe is emanating from one form, or called an absolute form, in this concept he uses a lot of philosophical thought theories, especially the theories of Polotinus thought, which says that "the One is there everywhere and there is no where" this concept really requires analytical and philosophical thinking so as not to lead to a wrong interpretation of the Oneness of Allah. In another statement that "Surely no one else has a form apart from it, what is meant by Sufistic philosophers is God, that there is no existence in this world besides God, that the essence of all things will be destroyed, except the face of His essence". ${ }^{13}$

In the Qur'an Surah 28 verse 88 it is intended that, "not in the sense that it is mortal eternally and forever and cannot be understood in any other way, in fact everything originates from Him in this case the existence of the universe, seen in itself and there is nothing but God Almighty and the face of His essence". ${ }^{14}$

\section{Concept of Wahdat al-Wujud}

The concept of Wahdat al-Wujud is one of the teachings that was sparked by Ibn Arabi and inspired by the teachings of Ibn Taymiyyah. The concept of Wahdat al-Wujud is one of the concepts that must be understood within the framework of Sufism, because Ibn Arabi himself was a Sufi.

Simply stated, Wahdat al-Wujud is a concept that states that everything in this universe is in possession of the essence of being which is the Creator's Khaliq form. According to Ibn Arabi, the essence of being is a form of Khaliq itself, because the form of Khaliq is united with all other forms. Here the Khaliq form is manifested in all the forms in the universe. Therefore, in essence Khaliq's form with the natural form is similar. Khaliq's form can be found in the form of nature, Khaliq's form is integrated with the form of nature.

According to Ibn Arabi, the universe was not created from nothing because the form of the universe was already in the form of God, and God did not have a beginning. Ibn Arabi also stated that the main purpose of man is the union with

\footnotetext{
${ }^{12}$ Ibid, 15

${ }^{13}$ Majid Fahri, Sejarah Filsafat Islam $2^{\text {nd }}$ Print, (Jakarta: Pt. Grafindo persada, 1971), p.346

${ }^{14}$ Translation of Al-Qur'an, "There is no deity except Him. Everything will be destroyed except His Face" (Al-Qashs)
} 
the Creator, this union is possible because there is no difference between abid (who worship) and Ma'bud (who is worshiped).

Ibn Arabi stated that although the form of God and the form of nature are the same, but this one form has the appearance and hiddenness. That is what then separates man from union with God. This unification can be done by way of Sufism so that ultimately God is the ultimate goal of everything.

The teachings of Ibn Arabi are then often identified with the teachings of pantheism that considers that God and nature are one entity. Pantheism states that nature and God are one form. God's form is manifested in nature.

However, the teachings of Ibn Arabi were later considered to be teachings that deviated from the mainstream of Islam. The concept that states that Khaliq and Beings are essentially the same is one of the main objections to the teachings of Ibn Arabi.

In the attributes of Allah, it is explained that Allah has the character of Mukhalafatu (Ta'ala) Lil Hawaditsi that means that Allah cannot be similar to His creature so that it is impossible that Khaliq will be the same as a creature. In addition, the concept that the universe was not created from nothing is also one of the main points of Ibn Arabi's teachings that are deemed incompatible with Islamic teachings as expressed in the Qur'an $\mathrm{Al}$ An'am verse 101 which translation is: He (Allah) created the heavens and the earth.

Ibn Sina (died 1027 AD), in the philosophy of his being, everything he had was divided into three levels as follows: (1) Obligatory Being, the essence which must have a form. Here the essence cannot be separated from being; both are the same and one. This essence does not start from nothing, and then come into being, but it is obligatory and must be in existence forever. Ibn Sina further divided Wajibul Wujud into Wajibul Wujud bi dzati and compulsory al-wujud bi ghairihi. The first category is the one with His being because of His essence alone, it is impossible if it is assumed not to exist. The second category is existence that is related to the existence of something other than its essence, (2) Mumkin alwujud, an essence that may have a form and may also be intangible. In other words, if it is assumed to not exist or is assumed to exist, then it is not impossible, may or may not exist. Mumkin al-wujud if seen in terms of its essence, it does not have to exist and it does not have to be non-existent because it is called Mumkinalwujud bi dzati. It can also be seen from the other side so that it is called Mumkin alwujud bi dzatihi and Wajib al-wujud bi ghairihi. Mumkin type includes everything that exists, other than Allah, (3) Mumtani' al-wujud, essence that cannot have form, as it is now also other cosmos besides this existing cosmos. ${ }^{18}$

${ }^{18}$ Sirajuddin Zar, Filsafat Islam; Filosof dan Filsafatnya, (Jakarta: Rajawali Press, 2017), p. 96- 
Ma'ruf Al-Karkhi (d. 200/815), a famous Sufi in Baghdad who lived four centuries before Shaykh Sheikh Ibn Arabi, is considered the first to express the creed with the words "There is nothing in existence except Allah", Abu al -Abbas Qassab (4th/10th century) expresses similar words: "There is nothing in the two worlds except my Lord, everything that exists (wantjudat) everything except His form is nothing (ma'ddm)". Whereas Al-Qunawi uses the term Wahdatul Wujud to show that the oneness of God does not prevent the appearance of diversity. Although One in His Substance or in relation to His tanzih, the form is many in its appearance or in its relationship in His tasybih. ${ }^{19}$

Another Sufi before Sheikh Ibn Arabi who more or less stated statements that were considered to contain the Wahdatul Wujud doctrine was Abu Hamid AlGhazali (d. $505 \mathrm{H} / 1111 \mathrm{AD}),{ }^{20}$ in one of his works stated "something that is true to the truth is Allah SWT, just as the true light is Allah SWT", "There is no being except Allah and His face, with that too, then everything perishes except His face in an eternal manner" The figure who would be most instrumental in popularizing the term Wahdatul Wujud is Taqi al-Din Ibnu Taimiyyah (w.728 H / $1328 \mathrm{AD}$ ), he was a strong critic of Sheikh Ibn Arabi and his followers, from the time of Ibn Taimiyyah onwards, the term Wahdatul Wujud is generally used to show all the doctrines taught by Sheikh Ibn Arabi and his followers. The definition of Wahdatul Wujud according to Ibnu Taimiyah is different from the understanding of Wahdatul Wujud of Shaykh Ibn Arabi. According to Ibn Taimiyyah Wahdatul Wujud is the equation of God with nature, the difference with Sheikh Ibn Arab is that he does not see the aspects of tanzih in the same teachings, he only sees from the side of Tasybih in the teachings of Sheikh Ibn Arabi. Though both aspects (tanzih and tasybih) are combined into one in the teachings of Sheikh Ibn Arabi. ${ }^{21}$

\section{History of Wahdāt al-Wujūd's Appearance}

The doctrine of Wahdāt al-Wujūd is always associated with Ibn 'Arabiī, because he is considered to be its founder. Although the Wahdāt al-Wujūd doctrine is related to the Ibn 'Arabi, doctrines that are roughly the same or similar to it have been taught by several Sufis long before Ibn 'Arabi. The Ibn'Arabì himself never used the term Wahdāt al-Wujūd, considered to be the founder of Wahdāt alWujūd because of his teaching which contained the theory of ideas about Wahdāt al-Wujūd. ${ }^{22}$

\footnotetext{
${ }^{19}$ Noer, Ibn Arabi; Wahdat Al-Wujud Dalam Perdebatan, p, 34-36.

${ }^{20}$ Ibid, p. 35

${ }^{21}$ Noer, hlm, 40

${ }^{22}$ Kautsar Azhari Noer, Ibn `Arabī; Wahdātal-Wujūd .... p.35
} 
Long before the development of Islamic mysticism (tasawwüf), classical philosophers had first talked about The One, wäjib al Wujūd (God), pluralism or dualism of the relationship between God and nature. Al-Kindî (died $873 \mathrm{CE}$ ), according to him God is only one, and there is nothing like God. God Almighty, apart from God all means a lot. God is perfect wujûd and not proceeded by other wujûd. ${ }^{23}$ His form does not end, while the other wujûd is due to His wujûd. The essence of God is true wujûd (al-Haqq) is the only reason, not the origin does not exist then came into being. He is always impossible not to exist, He is always there and always will be. Therefore, God is perfect wujûd that is not preceded by other wujûd, does not end His wujûd and there is no wujûd except with Him. ${ }^{24}$

Ibn Sina (died 1027 AD), in his wujûd philosophy, everything he had was divided into three levels as follows: (1) Obligatory al-wujûd, the essence that must have wujûd. Here the essence cannot be separated from wujûd; both are the same and one. This essence does not begin from nothing, then manifests, but it is obligatory and must be in existence forever. Furthermore, Ibn Sina divided compulsory al-wujûd into compulsory al-wujûd bi dzati and compulsory al-wujûd bi ghairihi the first category is that

His wujûd by reason of His essence alone is impossible if it is assumed to be absent. The second category is wujûd that is related to the cause of something other than its essence, (2) Mumkin al-wujûd, the essence that may have wujûd and may also be intangible. In other words, if it is assumed to be absent or presumed to exist, then it is not impossible, that is, may or may not exist. Mumkin al-wujûd if viewed in terms of its essence, it does not have to be there and it must not be absent because it is called mumkinal-wujûd bi dzatî. It can also be seen from the other side so that it is called mumkin al-wujûd bi dzatihi and obligatory al-wujûd bi ghairihi. Mumkin type includes everything that exists, other than Allah, (3) Mumtani'al-wujûd, and the essence that cannot have wujûd, as it is now also other cosmos besides this existing cosmos. ${ }^{25}$

Only God has the Absolute Wujûd, absolutely, while everything else has a dual nature. God as the first cause, He is free material, One, and Single in all things. It has no genus and deference, two mandatory elements of a definition, therefore there is no definition for it, only names. Immaterial, He is pure good, because only in the material the source of all shortcomings lies evil (bad). God is beloved and a lover, who is liked and who likes, He is the highest Beauty because there is no Beauty that is higher than being a pure intellect, far from all flaws. The existence of all beings can be justified as proof of the existence of God. God is the efficient cause of nature, not preceded by time. In other words, the relationship between cause and effect and from any of these causes, their coming will come to God as a

\footnotetext{
${ }^{23}$ Hasyimsyah Nasution, Filsafat Islam, (Jakarta: Gaya Media Pratama, 2015), p. 19

${ }^{24}$ Ahmad Hanafi, Pengantar Filsafat Islam, (Jakarta: Bulan Bintang, 1990), p. 77

${ }^{25}$ Sirajuddin Zar, Filsafat Islam; Filosof dan Filsafatnya, (Jakarta: Rajawali Press,2017), p. 96-97
} 
cause, acting in nature that moves continuously in its existing form, as a cause of itself or needed by others. ${ }^{26}$

The development of Islamic mysticism in the early 7th century, namely the emergence of Sufis who devoted themselves to the sanctity of life (wara $\vec{a}^{\prime}$ ), perseverance of worship $\left(k h u s y^{\wedge}\right)$ and contemplation ( $\left.f i k r\right)$ of the state of man and his relationship with his God, they discovering worldly splendor, such as Hasan Al-Basri (d.728) with his concepts of Khaûf and Raja', and one of the unforgettable ascetic female figures to this day, namely Rābi'ah Al-'Adawiyyah (d.801), she was the first time to introduce the concept of divine love as the main joint for religious life, one time, she was asked about whether she loved God or hated Satan, Rabiah also replied "my love for God has filled all my heart, so that there is no room for love anymore or hate other than Him". ${ }^{27}$

\section{Concept of Wahdat al-Wujud Ibn Arabi}

The Wahdat al-Wujud doctrine is always associated with Shaykh Ibn Arabi, because he is considered to be its founder. Although the doctrine of Wahdat alWujud is in line with what some Sufis have taught long before Sheikh Ibn Arabi. Sheikh Ibn Arabi himself never used the term Wahdat al-Wujud, he was considered as the founder, because his teachings contained theories or ideas about Wahdat alWujud. $^{28}$

The principal thinking of Sufism of Shaykh Ibn Arabi is Wahdat al-Wujud which can be interpreted as a unity of being. According to Shaykh Ibn Arabi, the essence of existence is only one, namely God, while the appearance that appears is only a shadow (illusion) of that one. ${ }^{29}$ Everything besides God does not exist in itself, it only exists as far as manifesting the form of God. Nature is the locus of appearances from God. ${ }^{30}$ This natural form is imaginary. This abundant and diverse nature is a manifestation or appearance of one being. From the standpoint of nature, nature is none other than God. But from the point of appearance, another realm from God. ${ }^{31}$

Through the Wahdatul Wujud doctrine he asserted that God is the only real existence. Everything in the universe is nothing. God is reality in all forms. One of his remarks in al-Futuhat al-Makkiyyah which is often quoted by many people is: "If only there were no He, and no I would not have existed". Or "Wa fi kulli syay'in

\footnotetext{
${ }^{26}$ Dedi Supriyadi, Pengantar Filsafat...... p. 136

${ }^{27}$ Majid Fakhry, Sejarah Filsafat Islam: Sebuah Peta Kronologis, (Trans: Zaimul Am, Bandung: Mizan, 2001), p. 85.

${ }^{28}$ Noer, p. 35.

${ }^{29}$ Totok Jumantoro \& Samsul Munir Amin, Kamus Ilmu Tasawuf, Jakarta: Amzah, 2012, p. 279.

${ }^{30}$ Azra et. al., Ensiklopedi Tasawwuf: II, p. 521

${ }^{31}$ Aboe Bakar Atjeh, Dunia Tasawuf, (Bandung: Sega Arsy, 2016), p. 10.
} 
lahu tadullu's ayah" ala annahu 'aynuhu" (and in all cases, there are signs that indicate that $\mathrm{He}$ is $\mathrm{He}$ ). At this time Sheikh Ibn Arabi also said, "I really see the truth in the realities in the names I do not see everything except me".

Wahdatul Wujud is God's Manifestation in the Cosmos. According to Shaykh Ibn Arabi, the existence of all these is only one and the form of being is 'ain the form of Khaliq. There is no difference between the two in terms of nature. This was concluded in his statement: "Subhana man khalaqal asya'a wahua 'ainuhu." "Glory be to God who created all things and He is an "ain." According to Sheikh Ibn Arabi, the form of nature is 'ain the form of Allah and Allah is the nature of nature. There is no difference between the qadim being called Khaliq and the new being called creature. There is no difference between abid and ma'bud. Even those who worship and those who are worshiped are one. ${ }^{32}$ For this statement, sheikh Ibn Arabi expressed it through his poetry:

\author{
"Servant is God, and God is servant. \\ For the sake of my syu'ur (feeling), who is the convert \\ If you say servant, even though he is God \\ Or you say God, which one is given taklif"
}

If between Khaliq and beings are one form, why do you see two? Sheikh Ibn Arabi replied: why humans do not look at it from one face, they see that both are Haq from one face and beings from the other face. If they look with one in 'ain, or both are two faces for the essence of one, they will know that the substance is one without number and does not separate. ${ }^{33}$

Next Sheikh ibn Arabi explained the relationship between God and nature. According to him, this world is the shadow of God, the realm of the tajalli and mazhar (appearance) of God. When Allah created this Nature, he also gave God attributes to everything. Nature is like a blurry mirror and like a lifeless body. Therefore, Allah created man to clarify the mirror. Nature is an appearance of asma, and a continuous nature of God. Without nature, His nature and asma lose their meaning and are always in the form of substances that live in His absolute fortune, which are unknown to anyone. ${ }^{34}$

In this statement in the book of Ad-Durrunnafis written by Sheikh M. Nafis bin Idris al-Banjari, the thoughts of Shaykh Ibn Arabi can be summarized as

\footnotetext{
${ }^{32}$ Ris'an Rusli, Tasawuf dan Tarekat; Studi Pemikiran dan Pengalam Sufi (Jakarta: Rajawali Press, 2013), p. 139.

${ }^{33}$ Ris'an Rusli, p. 140.

${ }^{34}$ Ris'an Rusli, p. 142.
} 
follows: (1) alam nuskhatul Haqqi (nature is God's text). (2) alam mir'atul Haqqi (nature is a reflection of God). (3) alam mazhar wujudullah (nature, proof of the form of God). (4) Alam 'ainul Haqqi (nature is the reality of God). ${ }^{35}$

Indeed, in Sufism there are four levels, namely: Shari'a, Tariqa, Hakikat, and Makrifat. Sheikh Ibn Arabi explains the four levels as follows: At the lower level (Shari'a) there is the formula: 'Yours and mine'. Namely, the law that guarantees individual rights and ethical relations between humans. At the level of riyadloh (Tariqa) there is a formula: 'Mine is yours and yours is mine'. Dervishes are expected to treat one another like brothers. At the level of Hakikat (essence) the formula is: 'There is no mine and no yours'. Advanced Sufis realize that all comes from God, and they only carry the mandate, and they have nothing. At the level of gnosis (makrifat): 'There is no me and no you'. At this level, the individual has acknowledged that everything is God, that there is nothing and that no one is separated from God. What is true at one level may not be true at another level. ${ }^{36}$

That the core of the concept of Wahdat al-Wujud Ibn Arabi is a form that is essentially one and the form of a being is 'ain its form Khaliq. Humans are a real shadow from God.

\section{Diversity of Being Comes from One}

According to Ibn Arabi that there is only one reality in existence, we see this reality from two different angles, the first "we understand the Haqq (real) which is seen as a phenomenal of all essences. Whereas the second Khalaq which is the manifestation of the essence (appearance)" ${ }^{15}$ the two views above suggest that God created everything in the universe is two real categories, visible and there is something that is relative or (supernatural) but both have the same essence that is the essence comes from Khaliq (God). So, one of the many is only a name for two subjective aspects of one reality, so it is a real unity but a variety in empiricism (Empirical diversity).

Because of this limitation of human thought and human non-existence in summing up the whole as a whole, we see it as a plurality of diversity in the form of each characteristic. Ibn Arabi expressed his feelings after he saw the phenomenon of nature and creatures as a whole by using Theological Logic, meaning that Ibn Arabi using his mind could not be separated from the control of the omnipotence of God, that between one and many relationships can not be separated from the values of the Divine.

${ }^{35} \mathrm{M}$ Nafis bin Idris Al-Banjarie, Permata yang Indah (ad-Durunnafis), trans. Haderanie H N (Surabaya: CV. amin, 2016), p. 127.

${ }^{36}$ James Fadiman and Robert Frager, Nyanyian Sunyi Seorang Sufi, trans. Helmi Mustafa (Yogyakarta: Pustaka Al-Furqon, 2007), p. 153.

${ }^{15}$ A.E. Affifi, Op Cit, p.25 
Ibn Arabi used the "metaphor" in himself by noting that he was moving because someone was moving, he gave the example of the mirror as a real metaphor that the source of the shadow itself came from one, in addition he also used the "metemor mathematic" by using the number one as a cause of the emergence of other numbers basically the number is sourced from the number one.

Many other metaphors related to the essence of nature as a whole, from all the phenomenals raised by Ibn Arabi, are basically sourced from several theoretical approaches used, such as: Ash'Ariyah, about 'Universal substance', as in the following expression, "the existence of God can be known rationally by paying attention to the universal creation of the world, the logical inevitability of a creator" ${ }^{16}$ The above expression can be studied as Ibn Arabi analyzed the natural phenomenon about the process of diversity, this is very relevant to the concept of universality of Imam Ash'ari. Then he also uses the Al-Hallaj approach theory with the concept of "Lauhut wa Nashut" This theory reveals that "God has the nature of Lauhut and Nashut nature, through maqomat then humans are able to mortal level" where humans have been able to eliminate their nashut (human nature) and those who increased is the nature of His Lahud (the nature of his God) so that this is where unification occurs as al-Hallaj's expression as follows: "Your spirit (God) has mingled with my spirit, like the mixing of khamar with clear water, if touched I will be touched (Alhallaj) because you (God) are me (Hallaj) in all things, I am the person I miss and the person I am is, we are two spirits united in one body, when you (God) see me, you see Him, when you see Him we are all seen" ${ }^{17}$

Thus, the expression Al-Hallaj that God is one (wahid) basically that there is no Allah except Allah Himself, humans "unite with God because humans have the nature of lauhud (the nature of God) and so do the opposite". Based on this theory Ibn Arabi studied in depth that everything in the universe has the nature of Lauhud (the nature of God) this study is in line with the Qur'anic concept of "Heaven and Earth glorify God" that is, creatures that exist on earth and in the sky everything is in God's lauhud nature so that He is tasbih. There is no doubt that through al-Hallaj's theory of the nature of Lauhud and the nature of Nashut which means two different realms and eventually merge in the pana 'Lahud and Nashut become names in the aspects of birth and mind.

The author analyzes that the most relevant theory used by Ibn Arabi is AlHallaj's theory, so what is called the nature of lauhud and nashut is a reflection of the diversity of God's creations in the universe that is inseparable from the

\footnotetext{
${ }^{16}$ Majid Fahry, to dominate this truth, Ash'ari stated that this world as a creation must have a creator, p. 346

${ }^{17}$ Laily mansur, Ajaran dan Teladan paraSsufi, $1^{\text {st }}$ Print, (Jakarta: PT. Raja Grapindo Persada 1996), p.112
} 
element of God. Philosophically, God hears, sees, has hands, but what Ibnu Arabi means is God immanently, in the sense that God has absolute will and power. God is only absolute in Him, so what He wants then He just said "Kun Fayakun" so then be.

He hears and sees in every manifestation, He has unlimited essence to all forms, in the sense of a transcendent God because He is above all limitations in all individuality as a universal substance, $\mathrm{He}$ is the essence of all that exists. ${ }^{37}$

Wujudul Mutlaq (Mutlaq Unity)

Basically, according to Ibn Sina, divinity is revolved around the philosophy of existence, that the nature of something depends on its form (existence), and each thing in nature which has only been determined by its condition and lies in the content of form, however, then God is absolute form which is the origin of all things. ${ }^{38}$

In "pantheism that is far away or the essence of God there is everything that exists, that whatever forms exist depend on the form of God so that Wahdat alWujud is not a substance or substance unit, because the existence other than God is only a mere shadow of the form of mutlaq. To better understand deeply about the absolute form of God or called absolute unity, it is essential that the form is only one that is Allah, while the other form is the one form of God that is emitted through tajally so that everything that shines emanates. "The existence of everything is essentially no different from one form so that the form is only one and always one it is called mutlaq unity". ${ }^{20}$

Ibn Sabi revealed that "the source of all that exists is the origin of all beings in the past, present and future". ${ }^{39}$ This means that the mutlaq can be seen in the relative with an immanent foundation that is spritual.

Actually this concept is sourced from the Qur'an, especially surah al-Hadid verse 3 and surah al-Qahsys verse 88 which explains that "He is the First and the Last, the Ascendent and the Intimate, and He is, of all things, Knowing." verse is interpreted through a philosophical approach, in this case the theory of

\footnotetext{
${ }^{37}$ McGiffert, A. C. (1908). Modern Ideas of God. The Harvard Theological Review, 1(1), 10-27. www.jstor.org/stable/1507529

38 el-Zein, A. H. (1977). Beyond Ideology and Theology: The Search For The Anthropology Of Islam. Annual Review Anthropology(6), 227-254.

${ }^{20}$ Rivay Siregar Loc Cit, p. 185

${ }^{39}$ Hallaq, W. B. (1984). Was the Gate of Ijtihad Closed? International Journal of Middle East Studies, 16(1), 3-41. www.jstor.org/stable/162939

${ }^{40}$ Choudhury, M. A. (2019). The Tawhidi Methodological Worldview: A Transdisciplinary Study of Islamic Economics. Springer.
} 
emanation, especially neo platonism, the notion of the beginning, the end, the saint and the inner shows that everything in this virtual world is a reflection of God's nature as an absolute being.

In the philosophical view, a theory emerges that explains the "Wajibul Wujud" and "Mungkinul Wujud" through the concept of "matter and form" (objects and forms) that what is meant to exist is the existence of God, which is indeed obligatory, whereas possible forms are objects and the form, as revealed by Imam Al-Gazali that "the obligatory form is Allah who no longer created it and the base of everything that is eternal, while all the worlds outside Himself (Allah) with all its secrets and oddities are called possible forms, because he is experiencing change, which has a beginning and an end, and submitting to God as the sole substance mandatory being". ${ }^{41}$

In a hadith Kudsi expressed as follows: "I am a hidden gift that I do not know, so I created creatures so that by knowing me"24 "This hadith is described by Ibn Arabi that what God intended in the creation of creatures in general and humans in particular is so that he can see and know himself in a form of his qualities and names". ${ }^{25}$ Then appear in a form that is in harmony with his existence so that He (Allah) is also revealed from a hidden gift that what is in God has been revealed after he created his creature.

From the form of mutlaq then comes the initial sense which is also called the al-kully mind or called by the essence of Muhammadiyah, the initial intellect is the origin of the events that exist, through this process as revealed by al-Farabi in his emit theory (Emanasi), "God as reason thinks about himself and from this thought arises another existence and God is the first form with that thought then the second form arises, then the second form thinks about the first form and from that thought arises the third form, and so on the first reason until the tenth sense as the form of the universe" 26

Ibn Arabi has revealed Emanasi Al-Farabi, by saying that "Nature is qadim, conceptually it has been in the science of God since azali, nature is said to be qadim because it is part of God, and nature is called huddus because it has form". ${ }^{27}$ Therefore, the absolute form is considered from the aspect as a place of dependence and the origin of everything that exists, then that is God, but when viewed from the aspect of its coverage or transcendence of all forms that exist as well as a source for the universe known as the essence of Muhammadiyah.

${ }^{41}$ Abu Bakar, Aceh, Sejarah Filsafat Islam, $4^{\text {th }}$ Print, Jakarta: CV Ramdhani 1991

${ }^{24} \mathrm{Abu}$ al- Wafa al-Ghanimi, Al-Tafzani, Sufi dari Zaman ke Zaman, $4^{\text {th }}$ Print, Trans. Dar alTasagafah. Li Al-nasyir Wa-al Tauzi, (Kairo, 1983), p. 203

${ }^{25}$ Ibid,

${ }^{26}$ Harun Nasution, Loc. Cit. p. 27

${ }^{27}$ Harun Nasution, "Nature and God are qadim that nature is in the state of qadim zamani and not qadim dzati and in nature there is the aspect of Ilahiyat transcendentally." 
If the absolute form as God is interpreted as the beginning of life for all living things, it is called "Nafs Kully", then what if viewed from the point of view of all objects which are manifestations of absolute form, it is said "Jizim Kully", then what if he is seen as material then he referred to as "Habaa or Hayulah", but according to Ibn Arabi that all that exists is essentially one or absolute unity and this is what is meant by the term "Al-Wihdatul Wujud". ${ }^{28}$

In the view of Ibn Arabi that there is no difference between the one with various creations (Khaliq wal makhluq) even if there is a difference then that person is just not able to see with the eyes of his heart so he can not understand the nature of what lies behind his body, this is only owned by wise people. ${ }^{29}$

\section{Conclusions}

In the concept of "al-Wihdatul Wujud" (Unity of Being), Ibn Arabi is a combination of Philosophy and Sufistic views. Besides that, Ibn Arabi used many metaphorical analogies by describing the existence of God in every creature in the universe, therefore whatever form, both in the sky and in the earth, each has an essence that is immanent or in nature deity. According to Ibn Arabi that the creation of nature is a series of processes on the form of Allah, as the source of all that is "al-Ada or Wajibul Wujud" that God is true as a source of mutlaq, while the possibility of the Existence is a form of all emanations that are derived from God or often referred to as Sunnahtu-Allah. In his studies, Ibn Araba used the theory of Lauhud and Nashut, this theory is the view of Al-Hallaj which explains that God has two attributes that are mahmudah and mazmumah means that in God there is compassion as in al-Asma Al-Husnah, whereas humans are part God "Al-Wihdatul Wujud" is essentially the One God Form, everything in this virtual world is his, so He said in his Word "We are from Him (Allah) will return to Him (Allah)".

\section{References}

Al-Qur'an dan terjamahannya

Abu Bakar, Aceh, Sejarah Filsafat Islam, $4^{\text {th }}$ Print, Jakarta: CV Ramdhani 1991.

E., Affi A, Filsafat Mistisis Ibnu Arabi, $2^{\text {nd }}$ Print, Jakata: PT. Gaya Media Pratama, 1995

${ }^{28}$ Rivai Siregar Loc Cit, p. 188

${ }^{29}$ Ibid, p. 189 always says "Subhana Allah" Glory be to Allah who creates everything from His Dzat that if we see Him, means we see ourselves, therefore if someone want to be close with God, even unite with God, then they have to know themselves first, because themselves are the copy from God. 
Beel, J., Gipp, B., and Wilde, E., "Optimizing Scholarly Literature for Google Scholar \& Co." Journal of Scholarly Publishing 41, No. 2, 2010: 176-190.

Choudhury, M. A. The Tawhidi Methodological Worldview: A Transdisciplinary Study of Islamic Economics, Springer, 2019.

el-Zein, A. H. "Beyond Ideology and Theology: The Search For The Anthropology Of Islam.” Annual Review Anthropology 6, 1977: 227-254.

Madjid, Fakhry, Sejarah Filsafat Islam, Jakarta: Dunia Pustaka Jaya, 1984.

Hamkah, Tasawuf Perkembangan dan Pemurniannya, Jakarta: Pustaka Panji mas, 1994

McGiffert, A. C. "Modern Ideas of God.", The Harvard Theological Review, 1, No. 1, 1980: 10-27. www.jstor.org/stable/1507529

Naser, Husein Sayid, Tiga Pemikir Islam, Ibnu Sina, Al-Suhrawardi, Ibnu Arabi, Beirut, 1971

Laily, Mansur, Ajaran dan Teladan para sufi, Jakarta: PT. Grafindo Persada, 1996

A., Mustofa H., Akhlak Tasawuf, $3^{\text {rd }}$ Print, Jakarta: Pustaka Setia, 1999.

Nasution, Harun, Filsafat dan Mistisisme dalam Islam, $6^{\text {th }}$ Print, Jakarta: PT. Bulan Bintang, 1989

Rivai, Siregar, Tasawuf dari Sufisme klasik ke New Sufisme, $2^{\text {nd }}$ Print, Jakarta: Raja Grafindo persada, 2000

Snyder, H., "Literature review as a research methodology: An overview and Guidelines.", Journal of Business Research, 104, 2019: 333-339. https://doi.org/https://doi.org/10.1016/j.jbusres.2019.07.039

T, Somo. E and Al-Robert, C.A. Short History of Philosophy, Trans. Pasaribu, H Saut, (Sejarah Filsafat), Yogyakarta: Yayayasan Banteng Budaya, 2002.

Yusuf, B. "Manusia Dan Amanahnya Kajian Teologis Berwawasan Lingkungan." Jurnal Aqidah-Ta, 2, No. 2, 2016: 125-143. 